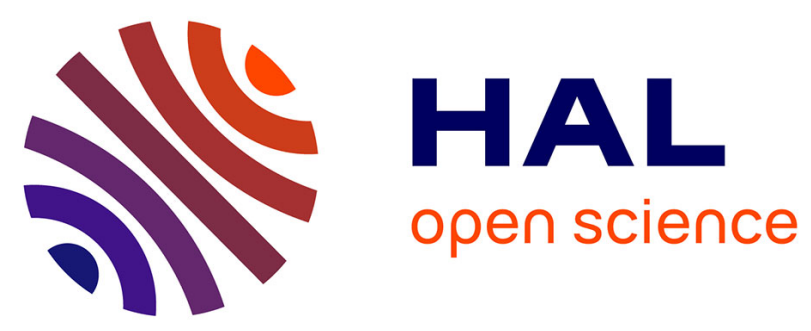

\title{
Efficiency of high- and low-voltage pulse combinations for gene electrotransfer in muscle, liver, tumor, and skin.
}

Franck M. André, Julie Gehl, Gregor Sersa, Véronique Préat, Pernille

Hojman, Jens Eriksen, Muriel Golzio, Maja Cemazar, Natasa Pavselj, Marie-Pierre Rols, et al.

\section{To cite this version:}

Franck M. André, Julie Gehl, Gregor Sersa, Véronique Préat, Pernille Hojman, et al.. Efficiency of high- and low-voltage pulse combinations for gene electrotransfer in muscle, liver, tumor, and skin.. Human Gene Therapy, 2008, 19 (11), pp.1261-71. 10.1089/hgt.2008.060 hal-00909581

\section{HAL Id: hal-00909581 https://hal.science/hal-00909581}

Submitted on 28 Nov 2013

HAL is a multi-disciplinary open access archive for the deposit and dissemination of scientific research documents, whether they are published or not. The documents may come from teaching and research institutions in France or abroad, or from public or private research centers.
L'archive ouverte pluridisciplinaire HAL, est destinée au dépôt et à la diffusion de documents scientifiques de niveau recherche, publiés ou non, émanant des établissements d'enseignement et de recherche français ou étrangers, des laboratoires publics ou privés. 


\title{
Efficiency of High- and Low-Voltage Pulse Combinations for Gene Electrotransfer in Muscle, Liver, Tumor, and Skin
}

\author{
F.M. Andrée, ${ }^{1,2}$ J. Gehl, ${ }^{3}$ G. Sersa, ${ }^{4}$ V. Préat, ${ }^{5}$ P. Hojman, ${ }^{3,6}$ J. Eriksen, ${ }^{3}$ M. Golzio, $, 6,7$ M. Cemazar, ${ }^{4}$ \\ N. Pavselj, ${ }^{5,8}$ M.-P. Rols, ${ }^{6}$ D. Miklavcic, ${ }^{8}$ E. Neumann, ${ }^{9}$ J. Teissié,,${ }^{6,7}$ and L.M. Mir ${ }^{1,2}$
}

\begin{abstract}
Gene electrotransfer is gaining momentum as an efficient methodology for nonviral gene transfer. In skeletal muscle, data suggest that electric pulses play two roles: structurally permeabilizing the muscle fibers and electrophoretically supporting the migration of DNA toward or across the permeabilized membrane. To investigate this further, combinations of permeabilizing short high-voltage pulses (HV; hundreds of $\mathrm{V} / \mathrm{cm}$ ) and mainly electrophoretic long low-voltage pulses $(\mathrm{LV}$; tens of $\mathrm{V} / \mathrm{cm})$ were investigated in muscle, liver, tumor, and skin in rodent models. The following observations were made: (1) Striking differences between the various tissues were found, likely related to cell size and tissue organization; (2) gene expression is increased, if there was a time interval between the HV pulse and the LV pulse; (3) the HV pulse was required for high electrotransfer to muscle, tumor, and skin, but not to liver; and (4) efficient gene electrotransfer was achieved with HV field strengths below the detectability thresholds for permeabilization; and (5) the lag time interval between the HV and LV pulses decreased sensitivity to the HV pulses, enabling a wider HV amplitude range. In conclusion, HV plus LV pulses represent an efficient and safe option for future clinical trials and we suggest recommendations for gene transfer to various types of tissues.
\end{abstract}

\section{Introduction}

$\mathbf{T}$ HE CONCEPT OF GENE ELECTROTRANSFER has developed from the first in vitro studies in 1982 (Neumann et al., 1982) to an efficient methodology for nonviral gene delivery in various tissues. Reviews have summarized the considerable interest in medical electroporation treatments for several tissues, for example, electrochemotherapy for subcutaneous tumors, including an increasing number of potential applications foreseen in preclinical trials (Andre and Mir, 2004; Mir et al., 2005; Cemazar et al., 2006; Heller and Heller 2006; Prud'homme et al., 2006).

In vivo, gene electrotransfer to muscle remains of particular interest, as transfer to this tissue enables long-term secretion of proteins for systemic therapy because of the longevity and secretory functions of muscles (Mir et al., 2005; Hojman et al., 2007a). However, gene electrotransfer to other tissues, including tumor tissue, is also of great therapeutic potential. Since the initial in vivo studies (Titomirov et al., 1991; Heller et al., 1996b; Aihara and Miyazaki, 1998; Mir et al., 1998a; Rols et al., 1998; Suzuki et al., 1998) and the optimization work in 1999 (Gehl and Mir, 1999; Mir et al., 1999), and because of reduced availability of other appropriate equipment, gene electrotransfer has essentially been performed with trains of identical pulses (Molnar et al., 2004; Mir et al., 2005; Wang et al., 2005). Results from experiments using combinations of short high-voltage (HV) pulses and long low-voltage (LV) pulses, however, permit deciphering of the mechanistic details for the understanding of gene electrotransfer into skeletal muscles (Bureau et al., 2000; Satkauskas et al., 2002, 2005).

Molecular physicochemical electroporation theory, based mainly on electro-optical and conductometric data on cells, suggests the presence of at least two types of transient per-

\footnotetext{
${ }^{1}$ CNRS, UMR 8121, Institute Gustave-Roussy, F-94805 Villejuif Cédex, France.

${ }^{2}$ Univ Paris-Sud, UMR 8121, France.

${ }^{3}$ Department of Oncology 54B1, Copenhagen University Hospital Herlev, DK-2730 Herlev, Denmark.

${ }^{4}$ Department of Experimental Oncology, Institute of Oncology, SI-1000 Ljubljana, Slovenia.

${ }^{5}$ Department of Pharmaceutical Technology, Université Catholique de Louvain, 1200 Brussels, Belgium.

${ }^{6}$ UMR 5089, IPBS du CNRS, F-31077 Toulouse, France.

${ }^{7}$ Université Paul Sabatier, Toulouse III, UMR 5089, France.

${ }^{8}$ Faculty of Electrical Engineering, University of Ljubljana, SI-1000 Ljubljana, Slovenia.

${ }^{9}$ Faculty of Chemistry, University of Bielefeld, D-33502 Bielefeld, Germany.
} 
meant structures: (1) a large number of transient short-lived "electropores" (membrane fluctuations) with a postpulse life time of a few milliseconds, and (2) a smaller number of larger, long-lived metastable permeation structures. The molecular basis for permeabilization is accounted for mainly by the these long-lived permeation structures, which are responsible for interactive mass transport of transiently membrane-adsorbed molecules across the membrane after the pulse. These structural features are instrumental for the analysis of the various data obtained with HV plus LV pulse combination modes and the effects of a time lag between the pulses.

The electric pulses play two roles: (1) permeabilization of the target cells and (2) enforcement of the electrophoretic transport of DNA toward (Henshaw et al., 2006), as well as across, the permeabilized membrane (Bureau et al., 2000).

The electroporator used in the present study was developed to deliver LV pulse(s) after a defined period of time after the HV pulse(s). Using different time lags between the $\mathrm{HV}$ and the LV pulses, it was found that in tibialis cranialis muscles the postpulse permeabilization of ${ }^{51} \mathrm{Cr}$-labeled EDTA persisted for $300 \mathrm{sec}$ after a single HV (100 $\mu \mathrm{sec}, 800$ $\mathrm{V} / \mathrm{cm}$ ). Nevertheless, LV pulse(s) remain effective in increasing the transfection efficiency even when delivered 50 min after the HV pulse (Satkauskas et al., 2002).

Therefore, an approach was started to characterize optimal conditions and pulse parameters for muscle, liver, tumor, and skin tissues. On the basis of the known efficiency of the combination modes (Satkauskas et al., 2002, 2005; Pavselj and Preat, 2005), the focus of this study has been on the four different tissues and on (1) the voltage amplitude of the HV pulse, (2) the voltage amplitude of the LV pulse, and (3) the time interval between the HV and LV pulses. By applying different methodologies to all four tissue types, the efficiency of the procedure was comprehensively evaluated, resulting in recommendations for gene electrotransfer in each case.

\section{Materials and Methods}

\section{Plasmid DNA}

All the groups have used the same plasmid constructs. Plasmid pEGFP-N1 (Clontech, Palo Alto, CA), encoding green fluorescent protein (GFP) under the control of a cytomegalovirus (CMV) promoter, was used for qualitative assessment of the efficiency of gene electrotransfer and for long-term follow-up studies of gene expression in skeletal muscle.

For precise quantification of the transfer efficiency, pCMVLuc+ (Clontech) encoding firefly luciferase under the control of a CMV promoter was used. The plasmids were amplified in Escherichia coli, and all plasmid preparations were performed with an EndoFree plasmid mega or giga kit (Qiagen, Chatsworth, CA) in accordance with the manufacturer's instructions and were dissolved in phosphate-buffered saline (GIBCO PBS; Invitrogen, Cergy Pontoise, France). The concentration and quality of the plasmid preparations were controlled by spectrophotometry and gel electrophoresis.

\section{Animals}

Animals were housed and handled according to recommendations of the European Convention for the Protection of Vertebrate Animals and with permission from respective national authorities. For the experiments on muscle, tumor, and skin, hair was removed from the treated area by depilation cream 1-2 days before DNA electrotransfer. For all experimental procedures, mice or rats were anesthetized by intraperitoneal administration of an anesthetic mixture containing ketamine hydrochloride (100 mg/ $\mathrm{kg}$ body weight) and xylazine (40 mg/ $\mathrm{kg}$ body weight). Mice were killed by quick cervical dislocation, whereas rats were killed by inhalation of diethyl ether.

Skeletal muscle. For all experimental procedures involving skeletal muscle, 7- to 9-week-old C57BL/ 6 female mice (Bomholtgaard [Ry, Denmark] or Janvier [Le Genest St Isle, France]) were used.

Tumor. B16-F1 melanoma cells, LPB fibrosarcoma cells, and SA-1 fibrosarcoma cells were cultured in vitro in Dulbecco's modified Eagle's medium (DMEM) or minimal essential medium (MEM) (Gibco; Invitrogen) supplemented with penicillin $(100 \mathrm{U} / \mathrm{ml})$, streptomycin $(100 \mathrm{mg} / \mathrm{ml})$, and $8 \%$ fetal calf serum (Gibco; Invitrogen). Young (6- to 8-weekold) C57BL/ 6 female mice (Bomholtgaard or Janvier) were inoculated subcutaneously via the left flank with $1 \times 10^{6}$ syngeneic B16 or LPB tumor cells (in $100 \mu$ l of MEM). SA-1 tumor cells $\left(5 \times 10^{5}\right)$ were injected into $\mathrm{A} / \mathrm{J}$ mice (Institute of Pathology, Medical Faculty, University of Ljubljana, Ljubljana, Slovenia). The tumors were treated when they reached an average diameter of 6-7 $\mathrm{mm}$ (7-8 days after inoculation).

Liver. Liver experiments were performed on 7- to 9-weekold C57BL/ 6 female mice (Janvier).

Skin. Skin experiments were performed on 8- to 10-weekold male Wistar rats (Janvier). Five to eight electroporation sites were placed on the back of each rat.

\section{DNA injections and electrodes}

Skeletal muscle. The tibialis cranialis muscles were injected with $10 \mu \mathrm{g}$ of plasmid in $20 \mu \mathrm{l}$ of PBS, using either a Hamilton syringe (RN type 4, 26-gauge with 16-mm-long needles) or an insulin injection needle (29 gauge). Injection was performed gently with an injection time of $15 \mathrm{sec}$. Two parallel external stainless steel plate electrodes (IGEA, Carpi, Italy) with a gap of 4 or $5.7 \mathrm{~mm}$ (width, $1 \mathrm{~cm}$; thickness, 1 $\mathrm{mm}$ ) were placed at each side of the leg and electrical contact was ensured by ultrasonography conductive gel (EKOGEL; EuroCamina, Egna, Italy). The electric field was placed perpendicular to the fiber axis. Pulsing was performed $30 \mathrm{sec}$ after DNA injection.

Tumor. Fifty micrograms of DNA in $50 \mu 1$ was injected intratumorally with a Hamilton syringe (RN type 4, 26 gauge with 16-mm-long needles). Injection time was between 15 and $25 \mathrm{sec}$. Two parallel external stainless steel plate electrodes (IGEA) with a gap of $5 \mathrm{~mm}$ were placed at each side of the tumor in order to encompass the whole tumor. Ultrasonography conductive gel (EKO-GEL; EuroCamina) was applied to ensure electrical contact between electrodes and skin. Pulsing was performed $30 \mathrm{sec}$ after DNA injection. 
Liver. For exposing the liver, a subxiphoid lateral incision was performed. Exerting a light pressure at each side of this incision allowed protrusion of the left liver lobe (main and largest lobe). Eighty micrograms of DNA in $100 \mu \mathrm{l}$ was injected intravenously to avoid direct transfer of the DNA to the liver cells in the absence of the electric pulses (Andre et al., 2006). The treated liver lobe was placed between two parallel stainless steel plate electrodes with a gap of $3 \mathrm{~mm}$ (width, $2 \mathrm{~cm}$; thickness, $1 \mathrm{~mm}$ ). Ultrasonography conductive gel (EKO-GEL; EuroCamina) was applied to ensure good contact between the electrodes and the liver. Pulsing was performed $3 \mathrm{~min}$ after DNA injection into the retro-orbital sinus. Injection time was between 20 and $25 \mathrm{sec}$. After gene transfer, the abdominal muscles and skin were sutured.

Skin. A skin fold was manually lifted from the underlying tissues and $50 \mu \mathrm{g}$ of DNA in $25 \mu \mathrm{l}$ was injected subcutaneously with a Hamilton syringe and a 30-gauge needle. Parallel plate electrodes with a gap of $4 \mathrm{~mm}$ and $1-\mathrm{cm}$ width were fitted around the skin fold. Ultrasonography conductive gel (EKO-GEL; EuroCamina) was applied to ensure electrical contact between electrodes and skin. Pulsing was performed $30 \mathrm{sec}$ after DNA injection.

\section{Pulse generators}

The various HV plus LV pulse combinations were generated with a Cliniporator (IGEA). Voltage and current traces corresponding to the actually applied voltages and actually measured current during the whole pulses were recorded and stored in the Cliniporator for evaluation of the actual electrical parameters. HV pulses and LV pulses were delivered in various train combinations with or without a time lag of $1 \mathrm{sec}$ between pulses. Alternatively, trains of eight identical electric pulses of 5-20 msec at intermediate electric field strengths were delivered with a P-15 GHT1287 electropulsator (Jouan, St Herblain, France).

\section{Luciferase activity measurement}

Mice were killed $48 \mathrm{hr}$ after electrotransfer, except for the experiments on liver, in which they were killed at $24 \mathrm{hr}$. Muscle, tumor, or liver tissue was removed, weighed, and put in a tube containing lysing matrix (Bio 101 Systems lysing matrix A tube; Q-Biogene, Illkirch, France) and $1 \mathrm{ml}$ of chilled cell culture lysis reagent solution (two tubes for the liver lobe), while 200-mg skin samples were cut into pieces and homogenized in $1 \mathrm{ml}$ of cell culture lysis reagent solution. For practical reasons, approximately half of the liver lobes were not weighed. The average left liver lobe weight was $311 \pm 32 \mathrm{mg}$. This value was used instead for the unweighed lobes. Cell culture lysis reagent (Promega, Madison, WI) was prepared from stock and supplemented with one tablet of protease inhibitor cocktail (Boehringer Mannheim, Mannheim, Germany). Tissues were homogenized and centrifuged at $12,000 \mathrm{rpm}$ for 10 $\mathrm{min}$. For muscle, tumor, and liver, luciferase activity was measured in $20 \mu \mathrm{l}$ of the supernatant, using a Lumat LB 9507 luminometer (Berthold France, Thoiry, France), by integration of the light produced over $10 \mathrm{sec}$, starting after the addition of $100 \mu \mathrm{l}$ of luciferase assay substrate (Promega) to the sample lysate. For skin, luciferase activity was assessed from 10 $\mu l$ of the supernatant, using a luminometer (TD-20/20 lumi- nometer; Promega), with a 3-sec delay time and integration over $15 \mathrm{sec}$, starting after the addition of $50 \mu \mathrm{l}$ of luciferase assay substrate (Promega) to the skin lysate. Results were collected from the luminometer as relative light units (RLU). Final results were expressed as picograms of luciferase per milligram of tissue by calibration with purified firefly luciferase protein (Promega).

\section{In vivo GFP expression follow-up}

GFP fluorescence was detected in live mice by whole body imaging, using a Leica MZFLIII stereomicroscope fitted with a Roper CoolSNAP charge-coupled device (CCD) camera (Leitz, Wetzlar, Germany). Image acquisition and analysis were performed with Metaview software. The sensitivity of the detection camera allowed for detection of GFP fluorescence emission across the skin of anesthetized animals. Alternatively, mice were killed $48 \mathrm{hr}$ after DNA electrotransfer and GFP expression in the transfected tissue was evaluated with a Nikon SMZ1500 fluorescence stereomicroscope (DFA, Copenhagen, Denmark) in blinded and randomized order. Gene expression was scored on the basis of the surface area of muscle fibers expressing enhanced green fluorescent protein (EGFP) on a scale from 0 to 5: 0, no EGFP expression; 1 , less than $20 \%$ of the muscle expresses EGFP; $2,20-40 \% ; 3,40-60 \% ; 4,60-80 \%$; 5 , more than $80 \%$ of the muscle surface expresses EGFP.

\section{Statistical analysis}

The number of muscles or animals (mice or rats) is reported for each experiment. Significance of the differences between groups was evaluated by Student $t$ test performed on the experimental values or on their logarithms. For statistical comparison of several groups, one-way analysis of variance (ANOVA) was performed. The figures present luciferase expression data as means $\pm \mathrm{SD}$.

\section{Results}

The results of the studies to optimize the voltage amplitude of the HV pulse confirmed previous data. For instance, increasing the duration or the number of $\mathrm{HV}$ pulses did not further improve transfer efficiency. In addition, we evaluated the effect of the LV amplitude, as well as the effect of using long low-voltage pulse $(400 \mathrm{msec})$ compared with eight pulses of $50 \mathrm{msec}$ at $2-\mathrm{Hz}$ repetition frequency (same total pulse duration). Finally, we analyzed the effects of a 1sec time interval between the HV and LV pulses.

\section{Skeletal muscle}

GFP expression in skeletal muscles after gene electrotransfer. In a first series of experiments, color fluorescent images on the transfection efficiency in muscles were obtained with GFP (Fig. 1). GFP expression was scored on the basis of the extension of fluorescent fibers in the treated muscle. A large range of amplitudes of the HV pulse was found efficient when the HV pulse was consistently followed by an LV of $400 \mathrm{msec}$ at the applied field strength of $80 \mathrm{~V} / \mathrm{cm}$ (Fig. 1). Applying a constant $\mathrm{HV}$ at $700 \mathrm{~V} / \mathrm{cm}$ followed by LVs of field strengths showed that efficient gene transfer was obtained with LVs of $400 \mathrm{msec}$ at 70-120 V/cm (data not shown). 


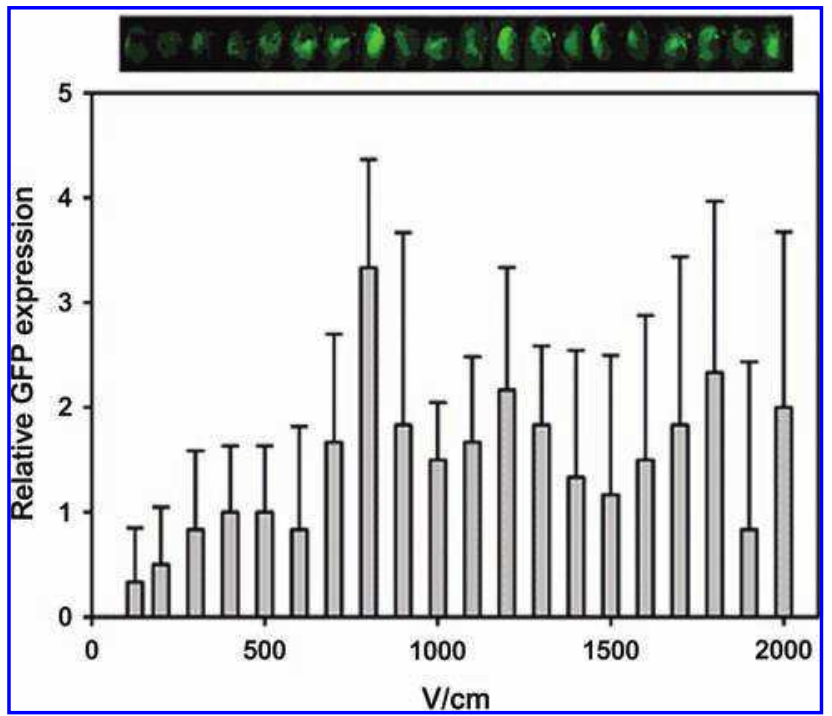

FIG. 1. Qualitative analysis of fluorescence in skeletal muscle after electrotransfer of GFP as a function of HV electric field strength $(\mathrm{V} / \mathrm{cm})$. Pictures were taken $48 \mathrm{hr}$ after electrotransfer, and the columns show mean fluorescence score $\pm \mathrm{SD}$ of six muscles. In comparison with the first level $(125 \mathrm{~V} / \mathrm{cm})$, there was significantly higher expression from $700 \mathrm{~V} / \mathrm{cm}$ and upward $(p<0.05)$.

The detection of GFP expression across the skin of the same animal was obtained over several weeks (Fig. 2). In two independent experiments, GFP expression after gene electrotransfer with the HV and LV combination was found to last longer than GFP expression after gene electrotransfer with the classical trains of eight pulses of $20 \mathrm{msec}$ at 200 $\mathrm{V} / \mathrm{cm}$ (data not shown).

Luciferase expression in skeletal muscle after gene electrotransfer. Quantification of the transfer efficiency was determined by measuring luciferase activity in the muscles. Two sets of experiments differing by the absence (Fig. 3a) or the presence (Fig. 3b) of a 1-sec time lag between the pulses were performed to assess the optimal amplitude of the HV. The electric field strength of the $100-\mu$ sec HV ranged from 200 to $1800 \mathrm{~V} / \mathrm{cm}$, while the LV was kept constant at a pulse duration of $400 \mathrm{msec}$ at $80 \mathrm{~V} / \mathrm{cm}$. These results confirmed the semiquantitative analysis (GFP), showing that a broad range of $\mathrm{HV}$ electric field strengths resulted in high levels of expression $48 \mathrm{hr}$ after gene electrotransfer.

Surprising differences were detected for the presence of a 1-sec lag between HV and LV pulses. In the presence of the lag we found that (1) the lowest HV field strength tested (200 $\mathrm{V} / \mathrm{cm}$ ) resulted in higher levels of expression than without the lag (Fig. 3a); (2) the range of efficient HV field strengths extended up to $800 \mathrm{~V} / \mathrm{cm}$ without a lag and up to $1200 \mathrm{~V} / \mathrm{cm}$ with the 1-sec lag; (3) the plateau of expression at these "optimal" values was about 10 times higher in the presence of the 1-sec lag between the HV and the LV pulses; and (4) no dramatic decrease in efficiency was observed at the highest field strengths tested (above $1400 \mathrm{~V} / \mathrm{cm}$ ) when there was a lag, in contrast to pulses without the 1-sec lag, for which expression almost disappeared at 1600 or $1800 \mathrm{~V} / \mathrm{cm}$. Comparisons with gene electrotransfer with $8 \times 20 \mathrm{msec}$ pulses showed that the presence of a lag between the HV and LV resulted in 10 times higher levels of expression level when using this pulse combination (Fig. 3b).

Thus, with the HV and LV pulse combinations there is no distinct "optimal" value but a range of efficient field strengths all giving rise to high expression levels. This is in contrast to the large decrease in expression found when using trains of rectangular pulses with amplitudes deviating from the optimal value (e.g., $50 \mathrm{~V} / \mathrm{cm}$ apart from the optimal field strength of $200 \mathrm{~V} / \mathrm{cm}$ [see Fig. 3]; see also Fig. 1 in Mir and coworkers [1999]).

\section{Tumor}

In B16 melanoma tumors, the effect of the field strength of the HV pulse, as well as the effect of a 1-sec lag between the HV pulse and the LV pulses, was monitored on the basis of luciferase activity (Fig. 4). With LV parameters identical to those found for skeletal muscle $(400 \mathrm{msec}$ at $80 \mathrm{~V} / \mathrm{cm})$ we found that higher HV field strengths $(800 \mathrm{~V} / \mathrm{cm})$ had to be applied to reach a plateau of expression and that almost no decrease in expression was found at the highest field strength $(2000 \mathrm{~V} / \mathrm{cm})$ tested (Fig. $4 \mathrm{a})$.

With an HV pulse with an amplitude of $1300 \mathrm{~V} / \mathrm{cm}$, the efficiency of gene electrotransfer was a function of the electric field strength of the LV component (Fig. 4c). Field strengths greater than $80 \mathrm{~V} / \mathrm{cm}$ were found to give efficient gene transfer in B16 melanomas. Even though there was no distinct peak, $140 \mathrm{~V} / \mathrm{cm}$ seemed to be an appropriate field strength for gene electrotransfer in tumors. Another tumor type, the fibrosarcoma SA-1 transplanted in A/J mice, showed similar results (data not shown). In the B16 melanoma model, comparisons between $1 \mathrm{HV}$ and $8 \mathrm{LV}$ (50 msec, $80 \mathrm{~V} / \mathrm{cm}$ ) and $1 \mathrm{HV}$ and $1 \mathrm{LV}(400 \mathrm{msec}, 80 \mathrm{~V} / \mathrm{cm}$; same to-

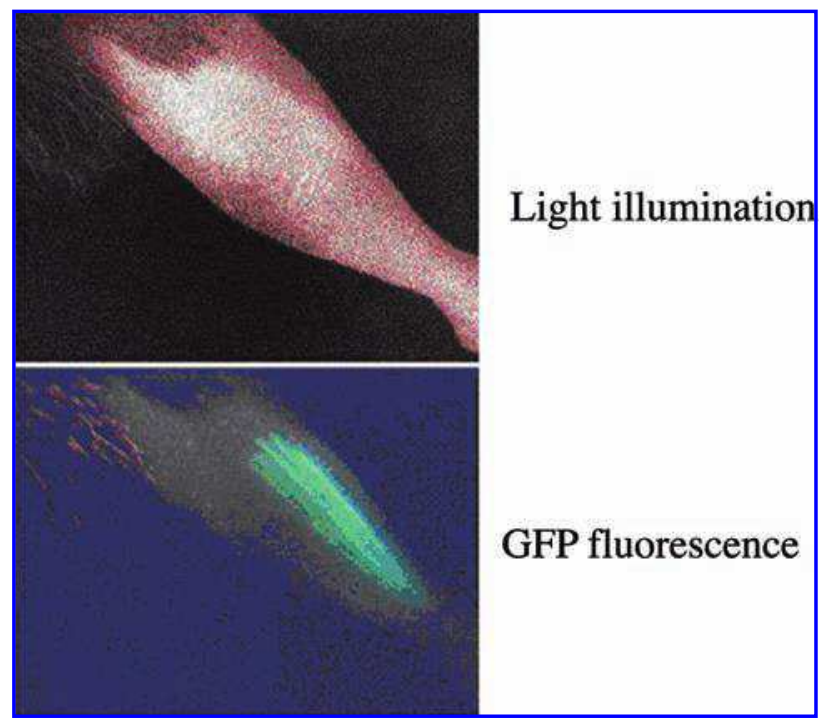

FIG. 2. Detection of GFP expression in muscles across the skin in vivo. The leg was observed under a stereomicroscope with a CCD camera. Top: Obtained by direct light. Bottom: Expressing fibers (in green) are clearly present under fluorescence detection. Pictures are representative images of the results on day 2 after electrotransfer, using HV plus LV combinations. 
FIG. 3. Quantitative analysis of expression of the luciferase gene in skeletal muscle as a function of $\mathrm{HV}$ electric field strength $(\mathrm{V} / \mathrm{cm})$. Measurements were performed $48 \mathrm{hr}$ after electrotransfer, using one HV of $100 \mu$ sec and one LV of $400 \mathrm{msec}$ at $80 \mathrm{~V} / \mathrm{cm}$ in the absence (a) or in the presence (b) of a 1-sec lag between the HV and the LV. Each group consisted of six mice, and data are presented as means $\pm \mathrm{SD}$ as described in Materials and Methods. LV-alone controls were previously published (Satkauskas et al., 2002, 2005). Statistical analysis showed significant differences between the groups of $\mathrm{HV}$ at $200 \mathrm{~V} / \mathrm{cm}$ versus injection alone in the presence of a lag $(p<0.001)$, but no significant difference in the absence of a lag (Bonferroni $t$ test). The highest values ( $\mathrm{HV}$ at 400,600 , and $800 \mathrm{~V} / \mathrm{cm}$ ) were significantly different from the second highest values (HV at 1000, 1200 , and $1400 \mathrm{~V} / \mathrm{cm})$ both in the absence $(p<$ $0.001)$ and in the presence $(p<0.05)$ of the lag. The highest HV amplitudes (1600 and $1800 \mathrm{~V} / \mathrm{cm}$ ) resulted in a significant difference from injection alone in the presence of a lag $(p<0.001)$ but not in the absence of a lag. The comparison of lag versus no lag for these four levels of expression (respectively: $200 \mathrm{~V} / \mathrm{cm}$; 400, 600, and $800 \mathrm{~V} / \mathrm{cm}$; 1000,1200 , and $1400 \mathrm{~V} / \mathrm{cm}$; and 1600 and 1800 $\mathrm{V} / \mathrm{cm}$ ) showed statistically significant differences $(p<0.001$ except for 400,600 , and $800 \mathrm{~V} / \mathrm{cm}$, for which $p<0.05)$.

FIG.4. Quantitative analysis of expression of the luciferase gene in B16 tumors as a function of the HV electric field strength (a), of the absence or presence of a 1-sec lag between the $\mathrm{HV}$ and the $\mathrm{LV}(\mathrm{HV}, 100 \mu \mathrm{sec}$ at $1300 \mathrm{~V} / \mathrm{cm}$; LV, $400 \mathrm{msec}$ at $140 \mathrm{~V} / \mathrm{cm})(\mathrm{b})$, and of the LV electric field strength (c). Measurements were performed $48 \mathrm{hr}$ after electrotransfer in groups of six mice. No statistically significant differences (except the difference from the injection-alone group) were found using either parametric tests (ANOVA with Bonferroni's correction) or nonparametric tests (Kruskal-Wallis).
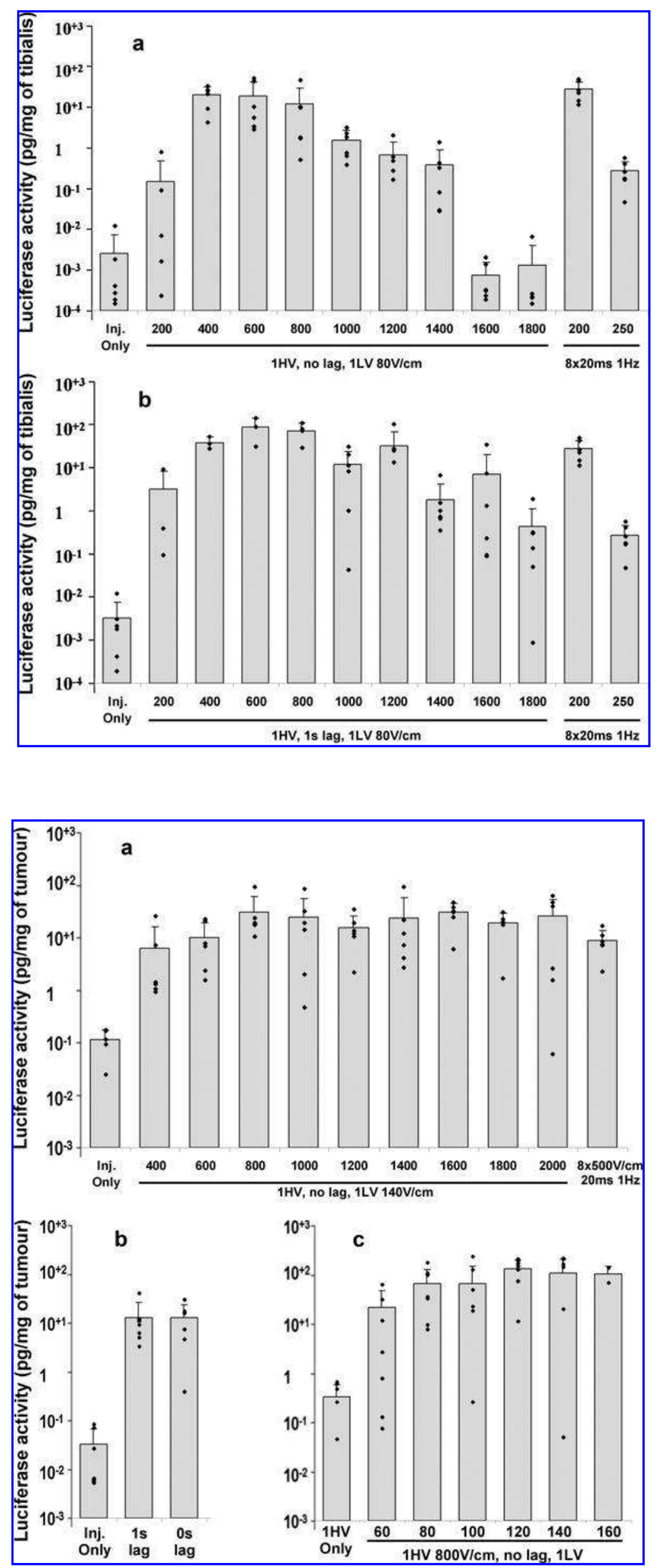
tal duration of the LV component) did not reveal a significant advantage (data not shown).

A 1-sec lag between the HV and LV pulses did not affect the level of maximal expression of the luciferase gene (Fig. $4 b)$. However, in the B16 tumors, higher voltages (1400 and $1600 \mathrm{~V} / \mathrm{cm}$ ) resulted in a decrease in luciferase expression in the absence of a lag.

\section{Liver}

For reasons described later (see Discussion), DNA had to be injected intravenously in a small volume $(100 \mu \mathrm{l})$ to perform an appropriate analysis of the effects of the HV and LV pulses on the efficiency of gene electrotransfer in mouse liver. The transfection efficacy of the HV pulse was tested on the basis of LV parameters $(400 \mathrm{msec}$ at $80 \mathrm{~V} / \mathrm{cm})$ that had been found optimal for gene electrotransfer in muscles. Contrary to skeletal muscle and tumors, none of the HV conditions tested resulted in any increase in luciferase expression compared with LV applications alone (Fig. 5a). Considering the possibility that the LV pulse of $400 \mathrm{msec}$ at $80 \mathrm{~V} / \mathrm{cm}$ was already permeabilizing liver cells, the field intensity was decreased and the experiments were repeated at $20 \mathrm{~V} / \mathrm{cm}$ (Fig. 5b). Thus in liver no HV is necessary if an LV of $400 \mathrm{msec}$ is delivered, even at low field strengths.

\section{Skin}

Gene electrotransfer to rat skin folds showed greater variability in luciferase expression than in muscle and tumors. To counterbalance this scattering, more repeats were performed for each experimental condition ( $n=8$ to 12), but with fewer experimental conditions (Fig. 6). A constant high level of gene expression was observed when increasing the HV amplitude from 700 to $1300 \mathrm{~V} / \mathrm{cm}$ (data not shown), similar to the situation in muscle. For LV pulses, a 27-fold increase in median luciferase expression with respect to the controls was reached with $1 \mathrm{HV}$ pulse $(1000 \mathrm{~V} / \mathrm{cm})$ and 1 $\mathrm{LV}$ pulse $(140 \mathrm{~V} / \mathrm{cm}, 400 \mathrm{msec})$, in the absence of a time lag between pulses (Fig. 6a). The presence of a lag resulted in higher luciferase activity, in particular with LV pulses of 140 $\mathrm{V} / \mathrm{cm}$ (Fig. 6b; data not shown for other LV field amplitudes). No difference was found between using one LV pulse of $400 \mathrm{msec}$ or eight LV pulses of 50 -msec pulse duration (data not shown).

\section{Discussion}

Optimizing HV and LV combinations to transfer genes in muscle, tumors, liver, and skin

The tissues tested needed different parameters, which was indeed expected because of the differences in tissue structure, cell size, and DNA distribution after injection. We also

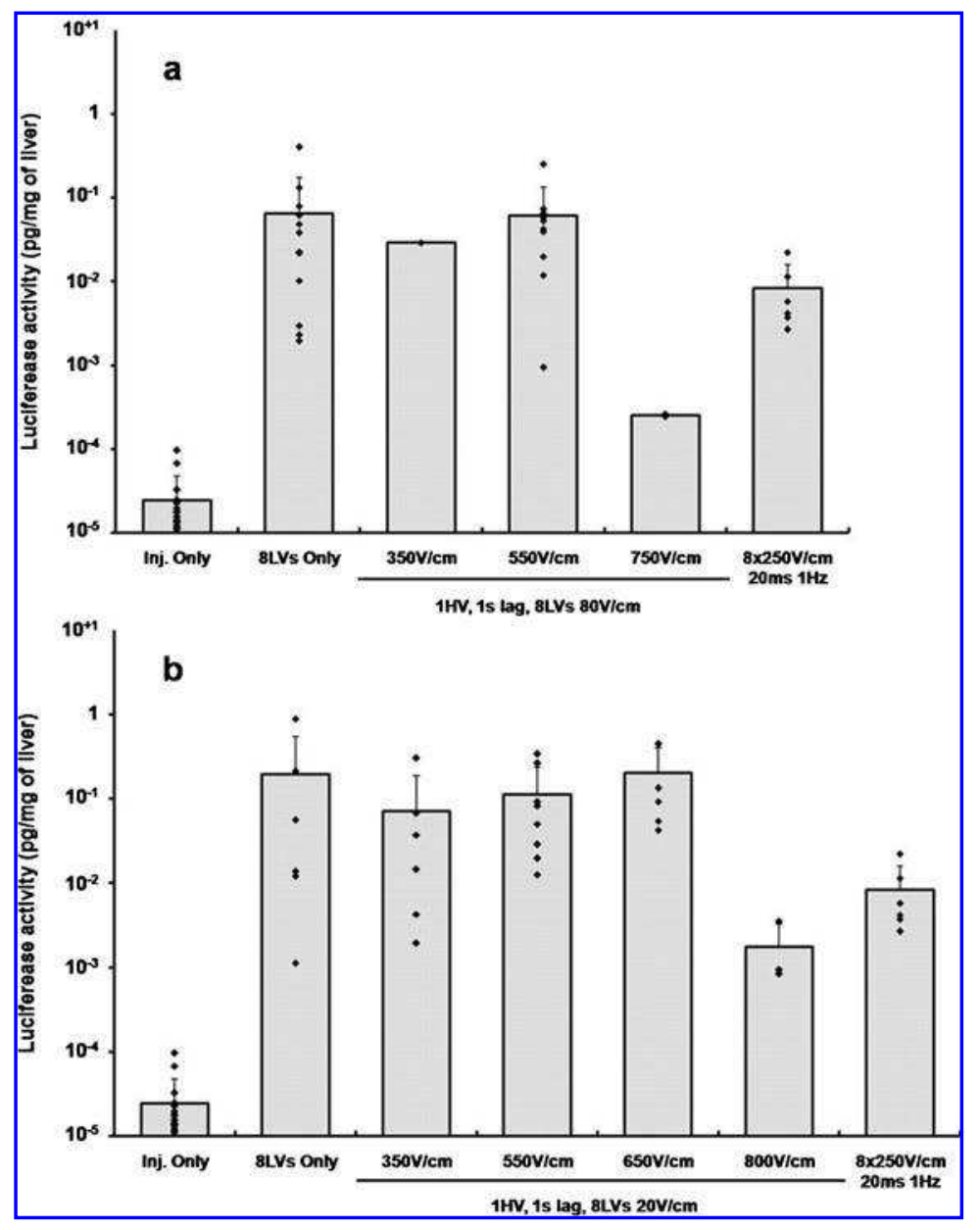

FIG. 5. Quantitative analysis of expression of the luciferase gene in liver as a function of the HV electric field strength, using LV electric pulses of either $80 \mathrm{~V} / \mathrm{cm}(\mathbf{a})$ or $20 \mathrm{~V} / \mathrm{cm}$ (b). Measurements were performed $24 \mathrm{hr}$ after electrotransfer. All electrotransferred groups were significantly different from the injection-alone groups. None of the HV plus LV groups showed any significant difference from the LV-only groups or the other HV plus LV groups, except under those conditions in which a too-high HV field amplitude $[750 \mathrm{~V} / \mathrm{cm}$ in (a) and $800 \mathrm{~V} / \mathrm{cm}$ in (b)] was applied. The HV $800 \mathrm{~V} / \mathrm{cm}$ plus LV group was significantly different from the injection-alone group (b), but not from the HV $750 \mathrm{~V} / \mathrm{cm}$ plus LV group (a). 
FIG. 6. Quantitative analysis of expression of the luciferase gene in rat skin as a function of the LV electric field strength (a) and of the absence or the presence of a 1-sec lag between the HV and the LV (b). One HV of $1000 \mathrm{~V} / \mathrm{cm}$ and $100 \mu \mathrm{sec}$ was delivered before the LV pulse of $400 \mathrm{msec}$. In (b), the LV pulse had a field strength of $140 \mathrm{~V} / \mathrm{cm}$. Measurements were performed $48 \mathrm{hr}$ after the electrotransfer and the results are represented on a log scale with picograms of luciferase per milligram of tissue of all the samples in each group. A normality test over the experimental groups failed, so the data are represented with a median (horizontal line), 25th and 75th percentiles (gray box), and 10th and 90th percentiles (error bars). Solid diamonds represent all the outliers. Each group comprised at least 8 samples, and on average 14 or 15 samples. LV-alone controls were previously published (Pavselj and Preat, 2005). Statistically significant differences were found between the control (inj. only) and the rest of the groups $(p<0.05$, one-way ANOVA, Dunn's test). No statistically significant difference was found between the delay of $1 \mathrm{sec}$ versus $4.2 \mathrm{sec}$ versus no delay or between the different LV amplitudes. showed that the HV and LV pulse combination allows a wide range of field strengths for maximal efficiency. Hence, slight deviations from the optimal experimental design (e.g., inhomogeneous electric field distribution due to the anatomy of the tissue) will have less consequence for gene transfer efficiency.

A great advantage of the HV plus LV pulse combination is the possibility to separately adapt the HV and LV pulse parameters. Independent control of HV and LV pulses has allowed determination of good parameters for efficient gene electrotransfer in the tissues explored: muscle, tumor, liver, and skin (Table 1). The recommendations listed in Table 1 are based on the results presented here and are limited to an experimental setup similar to ours. The recommendations, however, give us the opportunity to address some of the mechanisms underlying gene electrotransfer. For example, the inclusion of a time lag between the HV and LV pulse ensures maximal efficiency of the procedure but separates the pulses and thereby triggers two contractions. This is why the absence of a time lag is recommended if a single contraction/sensation is desired. Finally, recommendations also include previous theoretical knowledge concerning the temperature increase when electric pulses are delivered to tissues in vivo (Davalos et al., 2003): when minimal heating of the tissue is desired, it is recommended to split the 400msec pulses into several shorter pulses (e.g., eight pulses of $50 \mathrm{msec}$ ), as the period between consecutive LV pulses allows for dissipation of part of the electric energy of the electric pulses into heat. Yet the experimental efficiency is similar.

\section{Differential requirements for various tissues}

This study has revealed differences in the electrical parameters needed to ensure efficient gene electrotransfer in various tissues. In each tissue transfection efficiency depends on the DNA distribution and electric field distribution within the tissue. In particular, DNA distribution is different in different types of tissue (Andre et al., 2006; Mesojednik et al.,
2007). DNA distributes easily in muscle; in small rodents DNA disperses across whole muscle. In liver, on the other hand, we found it necessary to perform intravenous injection in order to avoid the hydrodynamic effect of the injection of fluid directly in the tissue (Liu et al., 1999). In all experiments the CMV promoter was used, and it should be noted that this promoter might show different levels of activity in different tissues.

\section{Differences in optimal field strength of high-voltage pulses}

Some of the differences between the tissues could be anticipated as they follow the predictions of biophysical knowledge about cell electropermeabilization. The higher HV field strengths required in tumors and skin (with respect to muscle) to reach the plateau value are rationalized in terms of the average cell diameter and shape differences between the cells of these tissues. Note in particular that muscle fibers are elongated rods with a long axis greater than the diameter of skin and tumor cells. This is in line with the quantitative expression relating the electrically induced change in the transmembrane potential difference with the geometric cell and tissue dimension (Neumann et al., 1999). In the case of B16 tumors, the fact that almost no decrease in expression was found at the highest field strength tested (Fig. 4a) might also be explained by the smaller cell size of B16 tumor cells compared with muscle fibers.

The observation that no HV is necessary to obtain efficient gene transfer in the liver is surprising. We have avoided transfer by a hydrodynamic-like procedure by injecting DNA intravenously in a reduced volume $(100 \mu \mathrm{l})$. The efficiency of DNA transfer in liver with only LV pulses possibly lies in the particular membrane features of hepatocytes. Moreover, hepatocytes are electrically connected through gap junctions. The conductive gap junctions permit viewing a cluster of hepatocytes as one big cell of large radius, such that the electric potential drop induced by the external field involves a large amplification factor. Hence small external field strengths might become effective in electroporating the hepatocyte cell membrane. 
Differences in optimal field strength of low-voltage pulses

Guided by previous attempts to optimize the LV component in skeletal muscle (Satkauskas et al., 2005), we tested only a low-voltage component of $400 \mathrm{msec}$ total duration, delivered as a single LV pulse of $400 \mathrm{msec}$ or as a train of eight LV pulses of 50 msec. LV pulses could affect DNA electrotransfer by promoting interstitial electrophoretic migration and thereby the distribution of DNA to cells in the tissue. Thus in principle the same parameters for the LV pulse may be effective. The experimental results, however, reflect a more elaborate situation: the LV parameters must be adapted in each case to the specific tissue (Table 1).

In liver, the efficiency of the low LV field strength (20 $\mathrm{V} / \mathrm{cm}$ ) could result from the following: (1) The electrodes are in direct contact with the tissue (thus, there is no voltage drop across the skin); (2) the tight connective cell architecture of the hepatocytes represents a continuous electrically conductive cell interior; and (3) there is no distension by DNA injection. The distance the DNA must be electrophoretically relocated is shorter than in the case of the three other tissues, where the DNA was injected locally. It should be noted that the low field strength values, as well as the lack of any necessity for an HV pulse, perfectly match the conditions found by other groups, demonstrating satisfactory gene electrotransfer efficiency in liver by trains of identical pulses at low field strength $(25$ to $50 \mathrm{~V} / \mathrm{cm}$ ) (Suzuki et al., 1998; Liu and Huang, 2002).

\section{Consequences of these findings for gene transfer efficiency and safety}

Recall that optimal gene expression with the HV and LV pulse combination in muscle, tumor, and skin is obtained with a rather large range of field intensities for the HV pulse (Figs. 3 and 4a). The electric field distribution within a tissue is not homogeneous (Miklavcic et al., 1998, 2000). Because, however, the transfection efficiency of the HV and LV pulse combination appears to be due largely to the electrophoretic displacement during the LV pulse, transfection with this pulse combination is less susceptible to the lack of homogeneity in the field distribution. In fact, in a large part of the tissue the local electric field intensity of the HV pulse will remain within the window of efficiency over a wide range of HV field strengths. With trains of identical pulses, the optimal field strength must be determined carefully because values of a few tens of $\mathrm{V} / \mathrm{cm}$ higher or lower than the optimum could result in large decreases in gene expression

Table 1. Recommendations for in ViVo Gene Electrotransfer in Various Tissues, Using Combinations of High and Low Voltage Pulses ${ }^{a}$

\begin{tabular}{|c|c|c|c|c|c|c|c|c|}
\hline \multicolumn{4}{|c|}{ High-voltage pulse(s) } & \multirow{2}{*}{$\begin{array}{l}\text { Interval } \\
\text { (duration } \\
\text { between } \\
\text { pulses; } \\
\text { sec) }\end{array}$} & \multicolumn{4}{|c|}{ Low-voltage pulse(s) } \\
\hline $\begin{array}{l}\text { Field } \\
\text { strength } \\
(\mathrm{V} / \mathrm{cm})\end{array}$ & $\begin{array}{c}\text { Pulse } \\
\text { duration } \\
(\mu \mathrm{sec})\end{array}$ & $\begin{array}{c}\text { Number } \\
\text { of } \\
\text { pulses }\end{array}$ & $\begin{array}{c}\text { Repetition } \\
\text { frequency } \\
(\mathrm{Hz})\end{array}$ & & $\begin{array}{c}\text { Field } \\
\text { strength } \\
(\mathrm{V} / \mathrm{cm})\end{array}$ & $\begin{array}{c}\text { Pulse } \\
\text { duration } \\
\text { (msec) }\end{array}$ & $\begin{array}{c}\text { Number } \\
\text { of } \\
\text { pulses }\end{array}$ & $\begin{array}{c}\text { Repetition } \\
\text { frequency } \\
\quad(\mathrm{Hz})\end{array}$ \\
\hline
\end{tabular}

Skeletal muscle, transcutaneous pulses

\begin{tabular}{rrrrrrrr}
600 & 100 & 1 & - & $0^{\mathrm{b}}$ & 100 & 400 & 1 \\
700 & 100 & 1 & - & $1^{\mathrm{c}}$ & $80^{\mathrm{d}}$ & 400 & 1 \\
700 & 100 & 1 & - & $1^{\mathrm{c}}$ & 100 & 400 & 1 \\
700 & 100 & 1 & $1^{\mathrm{c}}$ & 100 & 50 & $8^{\mathrm{e}}$ \\
\multicolumn{7}{c}{ Tumors, transcutaneous pulses } \\
1000 & 100 & 1 & - & 0 & 140 & 400 & 1 \\
1000 & 100 & 1 & - & 0 & 140 & 50 & $8^{\mathrm{e}}$
\end{tabular}

Liver, electrodes in direct contact with the tissue

\begin{tabular}{|c|c|c|c|c|c|c|c|c|}
\hline & - & 0 & - & - & 20 & 400 & 1 & $\overline{1}$ \\
\hline & - & 0 & - & - & 20 & 50 & $8^{e}$ & 1 \\
\hline & & & & & & & & \\
\hline 1000 & 100 & 1 & - & $0^{\mathrm{b}}$ & 140 & 400 & 1 & - \\
\hline 1000 & 100 & 1 & - & $1^{\mathrm{c}}$ & 140 & 400 & 1 & - \\
\hline 1000 & 100 & 1 & - & $1^{\mathrm{c}}$ & 140 & 50 & $8^{e}$ & 1 \\
\hline
\end{tabular}

aUsing plate electrodes.

${ }^{\mathrm{b}}$ To be used when a single contraction/sensation is desired.

'To be used when maximal efficiency of the procedure needs to be obtained.

${ }^{\mathrm{d}}$ To be used when no effect on the muscle is desired.

eTo be used when minimal heating of the tissue would be desired-the period between consecutive LV pulses allowing for dissipation of the heat generated by the electric pulses. 
(Gehl and Mir, 1999; Gehl et al., 1999; Mir et al., 1999; Cemazar et al., 2002). Thus, using the HV and LV pulse combinations allows manipulation over a wider range of therapeutic field strengths.

\section{Low levels of permeabilization are sufficient}

The lowest efficient HV pulse field strengths that ensure effective gene electrotransfer if combined with LV pulses are lower than previous estimations of the reversible electroporation detection threshold for eight consecutive pulses of the same duration as used here (Fig. 3) (Gehl and Mir, 1999; Gehl et al., 1999; Miklavcic et al., 2000). Hence gene electrotransfer can occur with electric pulses, which cause less intense membrane alterations than are needed for detectable diffusion of small hydrophilic molecules through the membrane (e.g., ${ }^{51}$ Cr-labeled EDTA) (Gehl and Mir, 1999; Gehl et al., 1999). Thus this indicates that low levels of electropermeabilization, which as such are experimentally under the detection limit, are already instrumental in gene electrotransfer.

This particular feature is reinforced by the fact that only one HV pulse is delivered in the HV plus LV combination. Electrochemotherapy protocols, in which the delivery of small molecules is required, always use six or eight HV pulses (Heller et al., 1996a; Mir et al., 1998b). Reversible and irreversible electropermeabilization thresholds have been determined with trains of eight pulses (Gehl and Mir, 1999; Gehl et al., 1999; Miklavcic et al., 2000). The high efficiency of gene electrotransfer achieved with a single HV pulse supports the concept that it is mandatory to destabilize the membrane of cells. However, the level of membrane perturbation can be lower than needed for detectable membrane permeabilization. If the actual permeabilization of the membrane is low, membrane resealing can be completed in a shorter time. This rationalizes the safety of the procedure.

\section{Influence of gap between HV and LV pulses}

Particularly in muscle, where the results are of lowest variability, a lag between the HV and LV pulses is an essential parameter for the efficiency of gene electrotransfer and in the choice of the electrical parameters. First, the optimal range of $\mathrm{HV}$ field strengths depends on whether or not there is a lag between the HV and LV pulses. With a lag, the range of optimal values was wider (in muscle, 400-1200 $\mathrm{V} / \mathrm{cm}$ instead of $400-800 \mathrm{~V} / \mathrm{cm}$ ). Moreover, at high $\mathrm{HV}$ field strengths, gene expression was not totally abolished if the time lag is present. This observation can be linked to more intense partial damage of the tissue (at least at 1600 and 1800 $\mathrm{V} / \mathrm{cm}$ ) without the lag because there would be no time for recovery of the cell membrane between the $\mathrm{HV}$ and $\mathrm{LV}$ pulses. Indeed, this effect of the lag can be analyzed through the theoretical knowledge of membrane electropermeabilization: it is widely accepted that (1) the external field strength determines the area of the cell membrane that will be electropermeabilized (Foster and Schwann 1989; Kotnik et al., 1997; Teissie et al., 1999), and (2) during pulsing a large number of defects (electropores) is generated (Teissie et al., 2005). According to the theories, most of these "electropores" reseal shortly after the end of the pulse. A fraction of the more stable defects (long-lived metastable permeation structures) reseal more slowly (Golzio et al., 2002). The half-life of these structures depends on the temperature. In summary, resealing is progressive, and recovery of membrane integrity can take seconds or minutes. Therefore, if no lag is applied between the HV and LV pulses, after-field transport can continue within the lag period through the electroporation-induced larger permeation passages. Because these transport passages reseal only slowly, a consecutive pulse meets the membrane during resealing and can support the electrophoretic cross-membrane electromigration of DNA. In the slow resealing phase most of the smaller electropores are resealed to a large extent, preventing any further, finally detrimental exchange of molecules and ions between cell interior and the outside.

\section{Conclusion}

Gene electrotransfer is a rapidly expanding field and knowledge about pulse optimization, and particularly important points regarding various tissues, are thus in demand. In this comprehensive study of muscle, tumor, skin, and liver, we have evaluated the use of combination pulses of high voltage and low voltage. Interesting organ-specific differences have been found. Potential side effects have also been evaluated, as shown in Hojman and coworkers (2007b, 2008).

The documented efficiency and safety of the HV plus LV pulse combinations will facilitate the transfer of DNA electrotransfer based on the HV plus LV pulse combination to the clinical level.

\section{Acknowledgments}

This study was supported by the European Commissions 5th framework program (Cliniporator, QLK3-1999-00484), as well as by national grants and support from local institutions (CNRS, IGR, AFM, and Region Midi Pyrenees). F.A. acknowledges the AFM for personal support. The authors also thank the staff of the various animal housing and handling facilities.

\section{Author Disclosure Statement}

Lluis M. Mir and Damijan Miklavcic are beneficiaries of patents licensed for use in the Cliniporator, produced by IGEA (Carpi, Italy).

\section{References}

Aihara, H., and Miyazaki, J. (1998). Gene transfer into muscle by electroporation in vivo. Nat. Biotechnol. 16, 867-870.

Andre, F., and Mir, L.M. (2004). DNA electrotransfer: Its principles and an updated review of its therapeutic applications. Gene Ther. 11, S33-S42.

Andre, F.M., Cournil-Henrionnet, C., Vernerey, D., Opolon, P., and Mir, L.M. (2006). Variability of naked DNA expression after direct local injection: The influence of the injection speed. Gene Ther. 13, 1619-1627.

Bureau, M.F., Gehl, J., Deleuze, V., Mir, L.M., and Scherman, D. (2000). Importance of association between permeabilisation and electrophoretic forces for intramuscular DNA electrotransfer. Biochim. Biophys. Acta 1474, 353-359.

Cemazar, M., Sersa, G., Wilson, J., Tozer, G., Hart, S., Grosel, A., and Dachs, G. (2002). Effective gene transfer to solid tumors using different nonviral gene delivery techniques: Electropo- 
ration, liposomes, and integrin-targeted vector. Cancer Gene Ther. 9, 399-406.

Cemazar, M., Golzio, M., Sersa, G., Rols, M.P., and Teissie, J. (2006). Electrically-assisted nucleic acids delivery to tissues in vivo: Where do we stand? Curr. Pharm. Des. 12, 3817-3825.

Davalos, R., Rubinsky, B., and Mir, L.M. (2003). Theoretical analysis of the thermal effects during in vivo tissue electroporation. Bioelectrochemistry 61, 99-107.

Foster, K.R., and Schwann, H.P. (1989). Dielectric properties of tissue and biological materials: A critical review. Crit. Rev. Biomed. Eng. 17, 25-104.

Gehl, J., and Mir, L.M. (1999). Determination of optimal parameters for in vivo gene transfer by electroporation, using a rapid in vivo test for cell permeabilization. Biochem. Biophys. Res. Commun. 261, 377-380.

Gehl, J., Sorensen, T.H., Nielsen, K., Raskmark, P., Nielsen, S.L., Skovsgaard, T., and Mir, L.M. (1999). In vivo electroporation of skeletal muscle: Threshold, efficacy and relation to electric field distribution. Biochim. Biophys. Acta 1428, 233-240.

Golzio, M., Teissie, J., and Rols, M.P. (2002). Direct visualisation at the single-cell level of electrically mediated gene delivery. Proc. Natl. Acad. Sci. U.S.A. 99, 1292-1297.

Heller, L.C., and Heller, R. (2006). In vivo electroporation for gene therapy. Hum. Gene Ther. 17, 890-897.

Heller, R., Jaroszeski, M., Glass, L.F., Messina, J.L., Rapaport, D.P., Deconti, R.C., Fenske, N., Gilbert, R., Mir, L.M., and Reintgen, D.S. (1996a). Phase I/II trial for the treatment of cutaneous and subcutaneous tumors using electrochemotherapy. Cancer 77, 964-971.

Heller, R., M.J. Jaroszeski, A. Atkin, D. Moradpour, R.A. Gilbert, J. Wands, and C. Nicolau. 1996b. In vivo gene electroinjection and expression in rat liver. FEBS Lett. 389, 225-228.

Henshaw, J.W., Zaharoff, D.A., Mossop, B.J., and Yuan, F. (2006). A single molecule detection method for understanding mechanisms of electric field-mediated interstitial transport of genes. Bioelectrochemistry 69, 248-253.

Hojman, P., Gissel, H., and Gehl, J. (2007a). Sensitive and precise regulation of haemoglobin after gene transfer of erythropoietin to muscle tissue using electroporation. Gene Ther. 14, 950-959.

Hojman, P., Zibert, J., Gissel, H., Eriksen, J., and Gehl, J. (2007b). Gene expression profiles in skeletal muscle after gene electrotransfer. BMC Mol. Biol. 8, 56.

Hojman, P., Gissel, H., Andre, F., Cournil-Henrionnet, C., Eriksen, J., Gehl, J., and Mir, L.M. (2008). Physiological effects of high- and low-voltage pulse combinations for gene electrotransfer in muscle. Hum. Gene Ther. 19, 1249-1260.

Kotnik T., Bobanovic, F., and Miklavcic, D. (1997). Sensitivity of transmembrane voltage induced by applied electric fields: a theoretical analysis. Bioelectrochem. Bioenerg. 43, 285-291.

Liu, F. and Huang, L. (2002). Electric gene transfer to the liver following systemic administration of plasmid DNA. Gene Ther. 9, 1116-1119.

Liu, F., Song, Y., and Liu, D. (1999). Hydrodynamics-based transfection in animals by systemic administration of plasmid DNA. Gene Ther. 6, 1258-1266.

Mesojednik, S., Pavlin, D., Sersa, G., Coer, A., Kranjc, S., Grosel, A., Tevz, G., and Cemazar, M. (2007). The effect of the histological properties of tumors on transfection efficiency of electrically assisted gene delivery to solid tumors in mice. Gene Ther. 14, 1261-1269.

Miklavcic, D., Beravs, K., Semrov, D., Cemazar, M., Demsar, F., and Sersa, G. (1998). The importance xof electric field distri- bution for effective in vivo electroporation of tissues. Biophys. J. 74, 2152-2158.

Miklavcic, D., Semrov, D., Mekid, H., and Mir, L.M. (2000). A validated model of in vivo electric field distribution in tissues for electrochemotherapy and for DNA electrotransfer for gene therapy. Biochim. Biophys. Acta 1523, 73-83.

Mir, L.M., Bureau, M.F., Rangara, R., Schwartz, B., and Scherman, D. (1998a). Long term, high level in vivo gene expression after electric pulse-mediated gene transfer into skeletal muscle. C. R. Acad. Sci. Paris 321, 893-899.

Mir, L.M., Sersa, G., Teissie, J., Domenge, C., Miklavcic, D., Jaroszeski, M.J., Orlowski, S., Reintgen, D.S., Rudolf, Z., Belehradek, M., Gilbert, R., Rols, M.P., Belehradek, J., Bachaud, J.M., Deconti, R., Stabuc, B., Cemazar, M., Coninx, P., and Heller, R. (1998b). Effective treatment of cutaneous and subcutaneous malignant tumours by electrochemotherapy. Br. J. Cancer 77, 2336-2342.

Mir, L.M., Bureau, M.F., Gehl, J., Rangara, R., Rouy, D., Caillaud, J.M., Delaere, P., Branellec, D., Schwartz, B., and Scherman, D. (1999). High-efficiency gene transfer into skeletal muscle mediated by electric pulses. Proc. Natl. Acad. Sci. U.S.A. 96, 4262-4267.

Mir, L.M., Moller, P.H., Andre, F., and Gehl, J. (2005). Electric pulse-mediated gene delivery to various animal tissues. Adv. Genet. 54, 83-114.

Molnar, M.J., Gilbert, R., Lu, Y., Liu, A.B., Guo, A., Larochelle, N., Orlopp, K., Lochmuller, H., Petrof, B.J., Nalbantoglu, J., and Karpati, G. (2004). Factors influencing the efficacy, longevity, and safety of electroporation-assisted plasmidbased gene transfer into mouse muscles. Mol. Ther. 10, 447-455.

Neumann, E., Schaefer-Ridder, M., Wang, Y., and Hofschneider, H. (1982). Gene transfer into mouse lyoma cells by electroporation in high electric fields. EMBO J. 1, 841-845.

Neumann, E., Kakorin, S., and Toensing, K. (1999). Fundamentals of electroporative delivery of drugs and gene. Bioelectrochem. Bioenerg. 48, 3-16.

Pavselj, N., and Preat, V. (2005). DNA electrotransfer into the skin using a combination of one high- and one low-voltage pulse. J. Control. Release 106, 407-415.

Prud'homme, G.J., Glinka, Y., Khan A.S., and Draghia-Akli, R. (2006). Electroporation-enhanced nonviral gene transfer for the prevention or treatment of immunological, endocrine and neoplastic diseases. Curr. Gene Ther. 6, 243273.

Rols, M.P., Delteil, C., Golzio, M., Dumond, P., Cros, S., and Teissie, J. (1998). In vivo electrically mediated protein and gene transfer in murine melanoma. Nat. Biotechnol. 16, 168-171.

Satkauskas, S., Bureau, M.F., Puc, M., Mahfoudi, A., Scherman, D., Miklavcic, D., and Mir, L.M. (2002). Mechanisms of in vivo DNA electrotransfer: Respective contributions of cell electropermeabilisation and DNA electrophoresis. Mol. Ther. 5, 133-140.

Satkauskas, S., Andre, F., Bureau, M., Scherman, D., Miklavcic, D., and Mir, L.M. (2005). Electrophoretic component of electric pulses determines the efficacy of in vivo DNA electrotransfer. Hum. Gene Ther. 16, 1194-1201.

Suzuki, T., Shin, B., Fujikura, K., Matsuaki, T., and Takata, K. (1998). Direct gene transfer into rat liver cells by in vivo electroporation. FEBS Lett. 425, 436-440.

Teissie, J., Eynard, N., Gabriel, B., and Rols, M.P. (1999). Electropermeabilization of cell membranes. Adv. Drug Deliv. Rev. 35, 3-19. 
Teissie, J., Golzio, M., and Rols, M.P. (2005). Mechanisms of cell membrane electropermeabilization: A minireview of our present (lack of?) knowledge. Biochim. Biophys. Acta 1724, 270-280.

Titomirov, A.V., Sukharev, S., and Kistanova, E. (1991). In vivo electroporation and stable transformation of skin cells of newborn mice by plasmid DNA. Biochim. Biophys. Acta 1088, 131-134.

Wang, X.D., Tang, J.G., Xie, X.L., Yang, J.C., Li, S., Ji, J.G., and $\mathrm{Gu}, \mathrm{J}$. (2005). A comprehensive study of optimal conditions for naked plasmid DNA transfer into skeletal muscle by electroporation. J. Gene Med. 7, 1235-1245.
Address reprint requests to: Dr. Lluis M. Mir UMR 8121, CNRS Institut Gustave-Roussy 39 Rue C. Desmoulins F-94805 Villejuif Cédex, France

E-mail: luismir@igr.fr

Received for publication May 13, 2008; accepted after revision August 21, 2008.

Published online: November 6, 2008. 

This article has been cited by:

1. Pernille Hojman, Hanne Gissel, Franck M. Andre, Christelle Cournil-Henrionnet, Jens Eriksen , Julie Gehl , Lluis M. Mir . 2008. Physiological Effects of High- and Low-Voltage Pulse Combinations for Gene Electrotransfer in Muscle. Human Gene Therapy 19:11, 1249-1260. [Abstract] [PDF] [PDF Plus] 